\title{
Pendapatan Komprehensif Lain Perusahaan Sektor Aneka Industri di Indonesia
}

Muhammad Kurniawan ${ }^{1}$

${ }^{1}$ Universitas Pancasila, Jl. Srengseng Sawah, Jagakarsa, Jakarta Selatan, 12640

INFO ARTIKEL

JEL Classsification:

M41

M16

E42

Keywords:

other comprehensive

income, financial

statement,

miscellaneous industry,

International Financial

Report Standars.

\section{$A B S T R A C T$}

The purpose of this study was conducted to investigate how the implementation of the presentation of other comprehensive income after the implementation of the International Financial Reporting Standards. Research subjects are various industry sectors. Other comprehensive income components tested are foreign exchange differences, employee benefits, available financial instruments sold, hedges, asset revaluation, associations and venture. The research object is 42 company data of miscellaneous industry sector. The data analysis method used is cross-tabulation and test of Cramer-V difference. The results of the study conclude that the other components of comprehensive income that are presented differently in the research subjects are foreign exchange differences, available financial instruments for sale, hedging, asset revaluation and association. While the other comprehensive component of the presented income is no different is the employee benefits and joint venture.

\begin{abstract}
A B S T R A K
Pujuan penelitian ini dilakukan untuk menginvestigasi bagaimana implementasi penyajian other comprehensive income setelah penerapan International Financial Reporting Standars. Subyek penelitian adalah sector aneka industry. Komponen penghasilan komprehensif lain yang diuji adalah selisih kurs, imbalan kerja, instrument keuangan yang tersedia dijual, lindung nilai, revaluasi aset, asosiasi, dan ventura. Obyek penelitian adalah 42 data perusahaan perusahaan sector aneka industry.Metode analisis data yang digunakan adalah tabulasi silang dan uji beda Cramer-V. Hasil penelitian menyimpulkan bahwa komponen penghasilan komprehensif lain yang tersaji berbeda pada subyek penelitian adalah selisih kurs, instrument keuangan yang tersedia dijual, hedging, revaluasi aset dan asosiasi. Sedangkan komponen penghasilan komprehensif lain yang tersaji tidak berbeda adalah imbalan kerja dan ventura bersama.
\end{abstract}

\section{Pendahuluan}

Sebuah perusahaan dalam kegiatan operasinya memiliki berbagai informasi, baik informasi masa lampau maupun informasi

masa depan. Informasi masa depan dapat juga disebut planning. Planning lebih menekankan pada perencanaan yang belum pasti namun 
diperhitungkan secara matang agar dapat dicapai. Informasi masa lampau merupakan record dari peristiwa-peristiwa dalam kegiatan perusahaan yang akan menjadi pertimbangan untuk menentukan planning.

Informasi masa lampau pada perusahaan sangat banyak, sehingga harus diorganisir untuk menjadikannya informasi yang lebih informatif. Dalam kegiatan perusahaan tentunya informasiinformasi yang terorganisir menjadi suatu bentuk informasi sistematis. Informasi ini tentu harus mencakup sesuatu yang paling sakral bagi sebuah perusahaan yaitu informasi terkait keuangan. Informasi sistematis terkait keuangan yang paling mendasar dan mencakup informasiinformasi yang lebih informatif bagi perusahaan secara umum adalah laporan keuangan.

Laporan keuangan idealnya dapat memberikan informasi dari aktivitas keuangan, posisi keuangan, keluar masuk kas, perubahan ekuitas, dan informasi lain terkait keuangan. Sesuatu yang ideal tentu memerlukan sesuatu yang dapat menyatukan ide-ide agar dapat diterima dalam jangkauan yang luas. Hal ini dapat juga disebut standar. Standar terkait laporan keuangan lebih dikenal dengan Standar Akuntansi Keuangan (SAK).

Standar IFRS menitiberatkan kepada penggunaan nilai wajar, terutama properti investasi, beberapa aset tak berwujud, aset keuangan, dan aset biologis (Cahyati, 2011:3). Nilai wajar (fair value) adalah suatu jumlah yang dapat digunakan sebagai dasar pertukaran aset atau penyelesaian kewajiban antara pihak yang paham dan berkeinginan untuk melakukan transaksi wajar.

Dahulunya PSAK mengacu pada Generally Accepted Accounting Principles (GAAP). Namun seiring waktu GAAP mulai dianggap tidak relevan terhadap kondisi sebenarnya. GAAP mulai ditinggalkan dan kini sebagian besar Standar Akuntansi Keuangan negaranegara di dunia termasuk Indonesia mengacu pada IFRS. IFRS yang dahulunya IAS dianggap lebih relevan karena menerapkan fair value (nilai wajar) pada standar pelaporannya. Berbeda dari GAAP yang masih menerapkan historical cost (nilai histori). Kondisi saat ini dengan era globalisasi menuntut penyeragaman standar di setiap negara secara luas. Karena dianggap lebih relevan, IFRS lebih mendunia. Hal ini tentu turut mendukung penyeragaman standar secara luas. Sebagian besar negara-negara di dunia sudah mulai melakukan konvergensi ke IFRS, baik adopsi penuh maupun adopsi dengan penyesuaian terhadap kondisi negara.

Informasi laporan keuangan merupakan unsur penting bagi investor, kreditor dan pelaku bisnis lainnya. Informasi yang dihasilkan laporan keuangan akan sangat bermanfaat bagi pengguna laporan keuangan apabila informasi tersebut relevan dan bermanfaat untuk pengambilan keputusan. Informasi yang tersaji dalam laporan keuangan pada hakekatnya menyajikan keterangan, catatan atau gambaran baik untuk keadaan masa lalu. Pemerintah Indonesia sebagai anggota The Group of Twenty (G20 Forum) telah bersepakat untuk melakukan konvergensi terhadap IFRS (www.iaiglobal.or.id, 2010). International Financial Reporting Standard (IFRS) adalah suatu upaya untuk memperkuat pondasi keuangan global dan mencari solusi jangka panjang mengenai transparasi laporan keuangan. Ikatan Akuntan Indonesia (IAI) dalam Gamayuni (2009), mencanangkan bahwa Standar akuntansi internasional (IFRS) akan mulai berlaku di Indonesia pada tahun 2012 secara keseluruhan atau full adoption. Pada tahun 2012 tersebut diharapkan Indonesia sudah mengadopsi keseluruhan IFRS.

Tujuan IFRS adalah memastikan bahwa laporan keuangan interim perusahaan untuk periode-periode yang dimaksudkan dalam laporan keuangan tahunan, mengandung informasi berkualitas tinggi yang: (1) Menghasilkan transparansi bagi para pengguna dan dapat dibandingkan sepanjang periode yang disajikan, (2) Menyediakan titik awal yang memadai untuk akuntansi yang berdasarkan pada IFRS, (3) Dapat dihasilkan dengan biaya yang 
tidak melebihi manfaat untuk para pengguna (Gamayuni, 2009).

Salah satu prinsip akuntansi adalah pengungkapan penuh (full disclosure), yang mana artinya bukan hanya menampilkan hal-hal yang baik saja, dan menyingkirkan bagian yang merugikan (Haryono, 2010). Pengungkapan dalam annual report merupakan salah satu isu penting di dunia pasar modal. Menurut Lynch (2000), laporan laba rugi merupakan bagian dari annual report yang paling dilihat stakeholders sebagai bahan pengambilan keputusan mereka. Laporan ini penting karena paling dapat menggambarkan kinerja perusahaan selama satu periode. Dalam menjalankan aktivitas operasinya pada sektor aneka industri pengungkapan dalam annual report harus mencukupi kebutuhan informasi para stakeholders dan sesuai dengan peraturan yang ada, maka diperlukan adanya corporate governance (Suhardjanto et al, 2012). Corporate Governance dapat didefinisikan sebagai suatu proses dan struktur yang digunakan oleh organ perusahaan (Pemegang Saham/ Pemilik Modal, Komisaris/ Dewan Pengawas dan Direksi) untuk meningkatkan keberhasilan usaha dan akuntabilitas perusahaan guna mewujudkan nilai pemegang saham dalam jangka panjang dengan tetap memperhatikan kepentingan stakeholder lainnya, berlandaskan peraturan perundang-undangan dan nilai-nilai etika (Sutedi, 2012).

Other Comperehensive Income (OCI) sebagai penerapan dari International Financial Reporting Standard (IFRS) tidak bisa dilepaskan dari laporan sebuah perusahaan. Otoritas Jasa Keuangan (OJK) dan Ikatan Akuntan Indonesia (IAI) sebagai regulator dan organisasai naungan juga harus terus memberikan pemahaman terhadap transformasi dari Standar Akuntansi Keuangan (SAK) kepada penerapan International Financial Reporting Standard (IFRS) secara penuh. Aneka Industri yang tercatat di bursa juga harus melakukan transformasi pelaporannya sejak tahun 2012 secara penuh. Other Comperehensive Income
(OCI) sebagai bagian dari laba rugi perusahaan menjadi penting dalam menyajikan laporan arus kas yang belum terealisasi secara akurat karena secara struktur dapat berpengaruh pada hubungan daya informasi dengan harga saham sehingga akan berpengaruh pada perubahan return nilai saham pada sektor industri tersebut.

Terus tumbuhnya aneka industri membuat perusahaan-perusahaan menjadi banyak perhatian para investor sehingga bukan hanya kinerja operasional saja yang dibutuhkan, akan tetapi kinerja pelaporan yang baik serta implementasi IFRS juga harus dilakukan agar laporan yang dihasilkan menjadi perusahaan yang transparansi serta mengikuti standar internasional. Penerapan IFRS menjadi sangat penting bagi perusahaan-perusahaan publik agar kinerjanya terus terjaga. Standar pelaporan yang baik dan dapat dipercaya secara internasional menjadikan perusahaaan akan terus tumbuh sehingga tidak hanya investor dalam negeri namun juga investor luar negeri akan tertarik.

Pengungkapan OCI ini bertujuan untuk meningkatkan transparansi dalam pelaporan pospos dalam laporan keuangan yang memberikan rincian atas laba rugi yang diperoleh perusahaan serta sumbernya. Dalam signaling theory manajemen mengirimkan sinyal kepada stakeholders. Publikasi laporan keuangan utamanya laporan laba rugi komprehensif juga merupakan sinyal yang positif/negatif, karena manager telah menyampaikan prospek masa depan nilai perusahaan ke publik, sehingga diduga dapat mempengaruhi harga saham. Dengan adanya pengungkapan OCI diharapkan akan meningkatkan relevansi nilai informasi akuntansi perusahaan publik di Indonesia. Informasi akuntansi yang berkualitas akan membantu investor/pengguna laporan keuangan dalam mengambil keputusan.

Sejalan dengan konvergensi IFRS pada tahun 2009, DSAK-IAI mengeluarkan PSAK No. 1 Penyajian Laporan Keuangan (Revisi 2009) berlaku efektif 1 Januari 2011 dan membawa banyak perubahan pada laporan 
keuangan perusahaan di Indonesia. PSAK No. 1 (revisi 2009) Penyajian Laporan Keuangan menetapkan dasar-dasar bagi penyajian laporan keuangan. Secara khusus PSAK No. 1 (revisi 2009) mengatur, pertimbangan menyeluruh untuk penyajian laporan keuangan, panduan tentang struktur laporan keuangan, persyaratan minimum untuk isi laporan keuangan. PSAK ini merupakan PSAK yang mengatur mengenai penyajian laporan keuangan bertujuan umum yang kemudian disebut juga sebagai laporan keuangan. Laporan keuangan bertujuan umum adalah laporan keuangan yang penyajian informasinya ditunjukan untuk seluruh pihak berkepentingan (stakeholder), hal ini dikarenakan adanya perbedaan kepentingan antar pihak pihak tersebut (stakeholder). PSAK ini dapat diterapkan untuk laporan keuangan semua entitas usaha baik individu maupun grup dalam bentuk laporan keuangan tahunan.

Other Comprehensive Income disajikan dalam tiga cara yaitu terpisah dengan laporan laba rugi, gabungan dengan laporan laba rugi, dan melaporkan pos-pos laba komprehensif dalam laporan perubahan ekuitas. Rima et al., (2014) memaparkan hasil penelitiannya bahwa dalam prakteknya Other Comprehensive Income disajikan dalam laporan laba (rugi) periode dan laba (rugi) komprehensif gabungan. Komponen Other Comprehensive Income yaitu perubahan surplus revaluasi, pengukuran kembali atas program manfaat pasti, keuntungan dan kerugian yang timbul dari penjabaran laporan keuangan dari kegiatan usaha luar negeri, pengukuran kembali aset keuangan tersedia untuk dijual, dan lindung nilai arus kas. Comprehensive Income disajikan dalam laporan laba rugi periode dan laba rugi komprehensif gabungan yaitu laporan laba rugi digabung dengan laporan laba rugi komprehensif yang hasil akhirnya dinyatakan dalam laba rugi bersih komprehensif.

Desy et al., dalam penelitiannya menjelaskan bahwa Variabel laporan keuangan (laba/rugi) sesudah penerapan IFRS juga tidak mempunyai pengaruh yang signifikan terhadap return saham. Hal tersebut dikarenakan tingkat laba yang menurun setelah adanya penerapan IFRS sehingga membuat return saham perusahaan tidak menghasilkan jumlah yang positif. Padahal pada kenyataannya terdapat perbandingan laporan keuangan (laba/rugi) sebelum penerapan IFRS dan variabel laporan keuangan (laba/rugi) sesudah penerapan IFRS. Perbandingan laporan keuangan (laba/rugi) yaitu terletak pada perubahan pada laporan laba rugi, dimana sebelum IFRS hanya mensyaratkan laporan laba rugi, dan sesudah adanya IFRS sekarang ini harus menyajikan laporan laba rugi komprehensif.

\section{Telaah Teori dan Pengembangan Hipotesis}

Teori sinyal adalah teori yang menjelaskan mengenai pemberian informasi kepada para pihak yang memerlukan laporan tersebut sebagai dasar pengambilan keputusan. Teori sinyal menurut Brigham (2001:39), (dalam Sakirman, 2016;32), merupakan suatu tindakan yang diambil manajemen perusahaan yang memberi petunjuk bagi investor tentang bagaimana manajemen memandang prospek perusahaan. Pemberian informasi perusahaan dalam pasar modal menjadikan teori sinyal berperan. Sinyalsinyal untuk memberitahukan apa saja yang terjadi dalam perusahaan mengenai operasinya membuat informasi menjadi berguna tidak hanya untuk para investor namun juga bagi regulator. Tidak adanya informasi yang menyimpang menjadikan investor akan terus tertarik pada perusahaan tersebut. Teori sinyal menyatakan pengeluaran investasi memberikan sinyal positif tentang pertumbuhan perusahaan di masa yang akan datang, sehingga meningkatkan harga saham sebagai indikator nilai perusahaan menurut Hasnawati (2005).

Laporan laba rugi adalah laporan yang mengukur keberhasilan kinerja perusahaan selama periode tertentu. Laporan laba rugi menyajikan rincian pendapatan, beban, keuntungan, kerugian, dan laba atau rugi 
perusahaan selama periode tertentu. Laporan laba rugi menunjukkan profitabilitas perusahaan dan return kepada para pemegang saham perusahaan untuk periode yang bersangkutan. Dengan pendekatan all inclusive-nya melalui tambahan istilah "komprehensif", laporan laba rugi dan pendapatan komprehensif lainnya kini tidak hanya menyajikan all owner changes in equity tetapi juga mengungkapkan all non owner changes in equity dengan memberikan rincian bagaimana laba atau rugi diperoleh disertai pengungkapan yang lebih banyak dalam catatan atas laporan keuangan.

Dalam akuntansi yang berbasis akrual, pendapatan diakui pada saat perusahaan menjual barang atau menyerahkan jasa dan ditandingkan dengan beban yang diakui untuk memperoleh barang atau jasa tersebut. Model akuntansi yang digunakan saat ini ketika perolehan awal aset atau liabilitas adalah berdasarkan biaya historis. Biaya historis menunjukkan biaya original aset dan liabilitas pada saat perolehan awal. Laba atau rugi ditentukan dengan mengaitkan beban dengan pendapatan yang diakui. Alternatif dari model biaya historis ini adalah akuntansi nilai wajar. Dengan model akuntansi nilai wajar, maka nilai aset dan liabilitas diukur dengan nilai wajar pada saat perolehan dan setelah tanggal perolehan jika ada indikasi perubahan nilai wajarnya.

Laba dengan model nilai wajar menunjukkan perubahan bersih dalam nilai wajar aset dan liabilitas selama satu periode, dimana keuntungan atau kerugian yang belum direalisasi juga diakui.

Perubahan tersebut muncul dengan direvisinya PSAK 1 (Revisi 2009). Perusahaan wajib menyajikan dan mengungkapkan Other Comprehensive Income (OCI) dalam laporan laba ruginya baik secara langsung dalam laba rugi maupun terpisah serta dalam catatan atas laporan keuangan. Laporan laba rugi komprehensif ini berisi perubahan-perubahan karena penggunaan model nilai wajar. Pengungkapan OCI ini bertujuan untuk mening- katkan transparansi dalam pelaporan pos-pos dalam laporan keuangan yang memberikan rincian atas laba rugi yang diperoleh perusahaan serta sumbernya.

Setiap keuntungan atau kerugian dari kelima pos-pos OCI diakui dalam laporan laba rugi komprehensif pada suatu periode tertentu disertai dengan pengungkapan dalam catatan atas laporan keuangan. Selain itu, perusahaan juga mengungkapkan jumlah pajak penghasilan terkait dengan pos-pos dari OCI, termasuk penyesuaian reklasifikasi, baik dalam laporan laba rugi komprehensif atau catatan atas laporan keuangan.

Humayun et al.,(2011), (dalam Sakirman 2016;17)membuktikanpendapatankomperhensif lain (OCI) mempunyai kemampuan untuk memprediksi arus kas dari kegiatan operasi satu tahun yang akan datang, meskipun kemampuan pendapatan komperhensif lain (OCI) untuk memprediksi net income satu tahun yang akan datang secara statistik tidak signifikan, dan tidak mempunyai relevansi nilai.

Sakiman (2016) mengungkapkan bahwa implementasi PSAK konveregensi IFRS di Indonesia diberlakukan secara mandatory mulai tahun 2012. Konsekuensi utama atas pemberlakuan tersebut adalah penerapan akun pendapatan komprehensif lain dalam laporan laba rugi komprehensif. Tujuan penelitian ini adalah mengivestigasi pengaruh net income, pendapatan komprehensif lain, securities dan non securities terhadap return. Penelitian juga mcmbuktikan pengaruh interaksi kualitas audit (Big 4) dengan komponen laba termasuk pendapatan komprehensif lain(oc) terhadap return. Amstrong et al., (2010), adopsi IFRS di Eropa terbukti secara umum direaksi oleh pasar positif. Beberapa kejadian yang menyangkut 16 aktivitas adopsi dan implementasi IFRS diamati selama tahun 2002 sampai dengan tahun 2005 dan terbukti mayoritas direaksi pasar secara positif, misalnya kejadian yang terkait keputusan parlemen Eropa untuk mengadopsi IFRS untuk perusahaan yang listing di bursa efek dan adopsi IAS 39 terkait fair value untuk hedging. 
Bahadir dan Toga (2013). observasi dilakukan pada 235 emiten pada bursa saham Turki terkait kebijakan akuntansi yang digunakan pasca implementasi IFRS. Turki mengadopsi IFRS mulai tahun 2005. Selama tahun pengamatan ditemukan bahwa terdapat perbedaan pilihan kebijakan akuntansi perusahaan publik di Turki, terutama terkait akun tanah, gedung dan peralatan. Leif et al., 2015), hasil penelitian menemukan bahwa diterapkannya akuntansi fair value menambah relevansi nilai atas laba. IFRS berorientasi pada laporan posisi keuangan dan menekankan pengukuran fair value. Terlihat berbeda, bahwa standar akuntansi keuangan berorientasi pada laba dan fokus pada biaya histori. IFRS juga berbeda dengan standar akuntansi keuangan yang memberikan pengakuan yang lebih pada aset tak berwujud secara keseluruhan, IFRS kurang konservatif dari pada standar kuntansi keuangan. Lachman et al., (2011), hasil eksperimen mengidentifikasikan investor non profesional kemungkinan kurang mendapatkan informasi atas perubahan risiko kredit ketika liabilitas tidak diukur pada nilai wajar. Apalagi fakta ditemukan banwa pengukuran nilai wajar merupakan pengembangan perhitungan berdasarkan intuisi bagi para investor non profesional.

Dengan adanya pengungkapan OCI diharapkan akan menurunkan tingkat asimetri informasi yang terjadi. Dengan semakin menurunnya tingkat asimetri informasi antara manajemen dan pemilik perusahaan, maka juga akan mempersempit ruang gerak bagi manajemen untuk melakukan praktik manajemen laba. Laporan laba rugi komprehensif merupakan laporan aktivitas kegiatan perusahaan dengan melihat hasil akhir pada tingkat keuntungan yang diperoleh sebuah entitas. Pasca adopsi IFRS, munculnya pendapatan komprehensif lain memberikan gambaran lebih pada informasi yang disajikan oleh laporan pendapatan komprehensif secara keseluruhan. Laporan terscbut tidak hanya mencatat transaksi historikal akan tetapi juga melihat arus kas masa depan.
Laporan pendapatan komprehensif lain merupakan pembentukan dan penjumlahan atas fakor dalam mengukur kewajaran nilai atas akunakun yang terdapat di dalamnya. Komponenkomponen dalam pendapatan komprehensif lain akan membentuk score dengan kriteria-kriteria yang ditetapkan. Semakin tinggi hasil penilaian daya informasi yang dihasilkan maka semakin mempunyai pengaruh positif terhadap informasi yang dihasilkannya. Oleh karena itu pendapatan komprehensif lain dan komponennya dinyatakan dalam:

OCI $1=$ Perubahan Nilai selisih Kurs Mata Uang Asing

OCI $2=$ Imbalan Kerja

OCI $3=$ Perubahan investasi Aset Keungan Tersedia untuk Dijual

OCI $4=$ Lindung Nilai Arus Kas/Hedging

OCI $5=$ Revaluasi Aset Tetap Berwujud dan Tidak Berwujud

OCI $6=$ Nilai Asosiasi

OCI $7=$ Nilai Ventura.

Berdasarkan uraian mengenai uji beda terhadap masing-masing kemponen-komponen pada pendapatan komprehensif lain dalam subsektor aneka industri maka dapat dirumuskan hipotesis:

H1: Terdapat perbedaan penyajian komponen perubahan selisih kurs mata uang asing pada subsektor aneka industri.

H2: Terdapat perbedaan penyajian komponen program imbalan kerja berdasarkan subsektor aneka industri.

H3: Terdapat perbedaan penyajian komponen sekuritas tersedia untuk dijual berdasarkan subsektor aneka industri.

H4: Terdapat perbedaan penyajian komponen lindung nilai arus kas berdasarkan subsektor aneka industri.

H5: Terdapat perbedaan penyajian komponen revaluasi aset tetap berwujud dan tidak berwujud beradasarkan subsektor aneka industri.

H6: Terdapat perbedaan penyajian komponen asosiasi pada subsektor aneka industri. 
H7: Terdapat perbedaan penyajian komponen asosiasi dan vertura pada subsektor aneka industri.

\section{Metode}

Penelitian tentang penyajian pendapatan komprehensif lain dan komponennya pada industri infrastruktur dan utilitis dilakukan dengan memperoleh data sekunder anatara lain di bursa efek Indonesia. Data sekunder yang diperoleh berfokus pada emiten-emiten pada perusahaan industri infrastruktur dan utilitis. Selain itu penelitian ini juga menggunakan studi dokumentasi dan dari berbagai sumber.

Penelitian ini menggunakan metode deskriptif kuantitatif, yaitu mengamati dan menganalisis objek penelitan yang terdiri dari komponen-komponen pada laporan pendapatan komprehensif lain (OCI) pada subsektor aneka industri. Data kuantitatif berupa angkaangka dan data diolah menggunakan uji beda. Sebelum dilakukan uji beda, mentabulasi angka serta memberikan gambaran baru serta teori baru atau membenarkan teori sebelumnya, karena penelitian ini melalui suatu proses pengujian empiris. Waktu penelitian dilakukan pada laporan keuangan khususnya laporan pendapatan komprehensif dan pendapatan komprehensif lain berserta komponennya pada sektor aneka industri yang terdaftar pada Bursa Efek Indonesia (BEI) periode tahun 20122015. Penelitian ini merupakan pengembangan dari penelitian sebelumnya yang dilakukan Sakirman (2016) tentang Pengaruh Income, Daya Informasi, Pendapatan Komprehensif Lain terhadap Return Saham dengan Kualitas Audit sebagai Variabel Pemoderasi. Pengembangan penelitian dilakukan fokus pada komponenkomponen pandapatan komprehensif lain (OCI) pada sektor aneka industri.

Dalam penelitian ini terdiri dari komponenkomponen pendapatan komprehensif lain yaittu perubahan selisih kurs mata uang asing (OCI 1), program imbalan kerja (OCI 2), perubahan investasi aset keuangan tersedia untuk dijual
(OCI 3), lindung nilai (OCI 4), revaluasi aset tetap berwujud dan tidak berwujud (OCI 5), selisih nilai asosiasi (OCI 6), dan selisih nilai ventura ventura (OCI 7).

\section{Hasil Penelitian dan Pembahasan}

Penyajian $O C I$ dalam penelitian ini mencakup penyajian atas Laporan Laba Rugi dan Pendapatan Komprehensif Lain dalam perusahaan sektor aneka industri yang tercatat dalam Bursa Efek Indonesia (BEI) selama tahun 2012 sampai dengan 2015. Adapun jumlah perusahaan yang terdaftar dalam BEI dan masuk dalam katagori sektor aneka industri sebanyak 42 perusahaan dengan rincian per subsektor Mesin dan Alat Berat sebanyak 2 perusahaan; subsektor Otomotif dan Komponen sebanyak 13 perusahaan; subsektor Tekstil dan Garment sebanyak 18 perusahaan; subsektor Alas Kaki (Footwear) sebanyak 2 perusahaan; subsektor Kabel sebanyak 6 perusahaan; dan subsektor Elektronika sebanyak 1 perusahaan.

Penyajian laporan keuangan dilakukan berdasarkan mata uang fungsional, rupiah atau USD. Sampel yang menyajikan laporan keuangan dalan USD dikonversi menjadi mata uang Rupiah dengan cara mengkalikan nilai komponen OCI dengan kurs tengah Bank Indonesia (BI) yang diperoleh peneliti dari situs resmi BI pada akhir tahun masing-masing laporan keuangan. Berikut daftar penyajian kurs tengah BI per tahun 2012 sampai dengan 2015 sebagai berikut: 
Tabel 1. Nilai Rata-rata $O C I$ dalam setiap Komponen PSAK (dalam Juta Rupiah)

\begin{tabular}{llllll}
\hline Komponen $\boldsymbol{O C I}$ & $\mathbf{2 0 1 2}$ & $\mathbf{2 0 1 3}$ & $\mathbf{2 0 1 4}$ & $\mathbf{2 0 1 5}$ & Mean \\
\hline PSAK10 - Selisih Kurs & 12.258 & 8.828 & 5.294 & 2.305 & 14.671 \\
PSAK24 - Imbalan Kerja & $15.165)$ & 3.628 & $7.539)$ & 2.771 & $(4.076)$ \\
PSAK55 - Tersedia untuk Dijual & $(2.654)$ & 4.475 & 2.822 & $(7.884)$ & 1.690 \\
PSAK55 - Lindung Nilai & $(3.485)$ & 4.785 & $7.912)$ & 14.504 & 1.973 \\
PSAK1619 - Revaluasi Aset & 11.452 & 8.230 & 4.143 & 7.034 & 10.215 \\
PSAK15 - Asosiasi & $(29)$ & 4.776 & 1.908 & 1.598 & 2.063 \\
PSAK15 - Ventura & $(3.433)$ & 4.473 & - & 2.642 & 921 \\
Other Comprehensive Income & $(1.056)$ & 79.195 & 8.716 & 22.970 & 27.456 \\
\hline
\end{tabular}

Sumber : Data diolah dengan menggunakan aplikasi SPSS

Pendapatan Komprehensif Lain : Selisih Kurs untuk Penyajian Laporan Keuangan

Berdasarkan hasil penelitian, pada perusahaan sektor aneka industri yang tercatat di Bursa Efek Indonesia hampir seluruh subsektor tidak mencapai 50\% yang menerapkan penyajian pendapatan komprehensif pada laporan laba rugi dan pendapatan komprehensif lainnya, kecuali pada komponen PSAK 24 (Imbalan kerja manfaat pasti) terlihat mulai tahun 2014 meningkat secara tajam, hal ini bisa jadi dikarenakan terkait dengan dukungan Peraturan Kementrian Ketenagakerjaan di Indonesia terkait dengan kewajiban perusahaan menyajikan dalam komponen PSAK 24 ini.

Penjabaran mata uang asing ke dalam mata uang pelaporan yang diakibatkan nilai kurs mata uang pada sektor aneka industri ada kecenderungan meningkat dari tahun 2012 sampai dengan tahun 2015. Hal tersebut lebih disebabkan karena kenaikan nilai kurs dari Rp. 9.670 pada tahun 2012, menjadi Rp.12.250 pada tahun 2013, kemudian pada tahun 2014 menjadi Rp.12.440, dan menjadi Rp.13.795 pada tahun 2015. Hal ini terlihat atas persentase dari hasil pengolahan data khususnya ini bahwa pada tahun 2012 persentase emiten yang menyajikan OCI terkait dengan PSAK 10 ini sebesar 23,80\%, hal serupa terjadi pada tahun 2013 yaitu sebesar 23,80\%. Peningkatan terjadi pada tahun 2014 dan tahun 2015, yaitu sebesar 26,20\%.

Transaksi-transaksi selama tahun berjalan dalam mata uang asing dicatat dengan kurs yang berlaku pada saat terjadinya transaksi. Pada tanggal pelaporan, aset dan kewajiban moneter dalam mata uang asing disesuaikan untuk mencerminkan kurs yang berlaku pada tanggal tersebut. Keuntungan atau kerugian kurs yang timbul dikreditkan atau dibebankan dalam laporan laba rugi komprehensif tahun yang bersangkutan. Berdasarkan hasil riset dapat disimpulan bahwa emiten yang tercatat di Bursa Efek Indonesia pada sektor aneka industri ini masih belum banyak yang melakukan perluasan usahanya di luar negeri.

\section{Pendapatan Komprehensif Lain : Imbalan kerja}

Perkembangan yang terjadi pada PSAK 24 dalam terkait dengan imbalan kerja terhadap perusahaan dalam sektor aneka industri yang tercatat di Bursa Efek Indonesia dalam kurun waktu tahun 2102 sampai dengan tahun 2015 mengalami perubahan yang sangat signifikan, yaitu terjadi peningkatan yang tajam mulai tahun 2014. Dari hasil pengolahan data pada tahun 2012 dan tahun 2013 pada penyajian PSAK 24 terhadap perusahaan sektor aneka industri ini tercatat hanya 4,8\% yang menyajikan, akan tetapi pada tahun 2014 terjadi penngkatan yang tajam yaitu dengan total yang menyajikan sebesar 76,2\%. Pada tahun 2915 terjadi penngkatan kembali yaitu dengan total peningkatan sebesar $78,6 \%$. 
Dengan terbitnya Undang-undang Ketenagakerjaan Nomor 13 Tahun 2003 (UUK No. 13/2003) yang mewajibkan semua perusahaan memberikan beberapa imbalan mulai dari imbalan istirahat panjang sampai dengan imbalan Pemutusan Hubungan Kerja (PHK). Penerapan UUK tersebut diatur kebih lanjut dalam Peraturan Perusahaan (PP) atau Perjanjian Kerja Bersama (PKB). Perbedaan antara PP dan PKB bisa dilihat dari Pihak yang terlibat, kompleksitas, kedetailan dan jenis industri entitas.

Salah satu pasal dalam UUK tersebut mengatur tentang Imbalan Pasca Kerja, yakni imbalan yang harus diberikan perusahaan kepada karyawan ketika karyawan sudah berhenti bekerja dengan beberapa alasan diantaranya, karyawan terlibat tindak pidana, karena karyawan melakukan kesalahan berat, karena karyawan memasuki usia pensiun, karena karyawan meninggal dunia, karena karyawan sakit berkepanjangan, karena karyawan mengundurkan diri, karena perusahaan pailit, karena perusahaan mengalami kerugian dan alasan lainnya yang termasuk imbalan yang dibayarkan ketika karyawan sudah tidak aktif lagi bekerja. Sehingga Perusahaan harus melakukan Pencadangan (accrued) biaya yang akan dikeluarkan kelak, namun tidak semua alasan tersebut harus dilakukan pencadangan sesuai PSAK 24, diantaranya:

1. Imbalan Pasca Kerja Karena Karyawan Pensiun.

2. Imbalan Pasca Kerja Karena Karyawan Sakit Berkepanjangan/ Cacat.

3. Imbalan Pasca Kerja Karena Karyawan Meninggal Dunia.

4. Imbalan Pasca Kerja Karena Karyawan Mengundurkan diri (secara baik-baik).

Beberapa alasan peusahaan menerapkan PSAK 24 adalah :

1. Accrual basis, perusahaan harus mempersiapkan (mencadangkan/ mengakui) liabilitas (utang) untuk imbalan yang akan jatuh tempo nanti.
2. Tidak ada kewajiban yang tersem-bunyi, apabila di laporan keuangan perusahaan tidak ada account imbalan kerja, maka secara tidak langsung perusahaan sebenarnya "menyem-bunyikan" kewajiban untuk imbalan pasca kerja.

3. Arus kas di perusahaan, perusahaan lebih baik mengurangi laba yang diperoleh setiap periode berjalan, dibandingkan mengeluarkannya secara langsung ketika terdapat keryawan yang purna tugas.

Dalam perkembangannya PSAK 24 (Revisi 1994) hanya mengatur tentang akuntansi biaya manfaat pensiun. Bukan mengatur tentang dana pensiun seperti yang terdapat pada PSAK 18: Akuntansi Dana Pensiun. 10 tahun berselang, DSAK mengeluarkan PSAK 24 (Revisi 2004) yang mempunyai cakupan lebih luas, tidak hanya mengenai manfaat pensiun, akan tetapi mengatur semua imbalan kerja yang berlaku di Perusahaan. PSAK 24 (Revisi 2010) adalah PSAK 24 versi terbaru (sampai saat ini berlaku) yang berlaku efektif tanggal 1 Januari 2012, dimana PSAK ini adalah adopsi dari International Accounting Standar Nomor 19 (IAS 19) Revisi tahun 2009. IAS 19 terbaru telah dirilis pada tahun 2011 dan berlaku efektif setelah tanggal 1 Januari 2013, untuk menyesuaikannya, DSAK telah merilis pula PSAK 24 (Revisi 2013).

PSAK 24 mengatur ruang lingkup dan jenisjenis imbalan kerja yang harus diungkap-kan. Berdasarkan ketentuan atau peraturan, Imbalan Kerja yang harus diungkapkan adalah:

1. Imbalan yang diatur dalam program atau perjanjian formal, misalkan PP atau PKB.

2. Imbalan yang diatur dalam peraturan perundangan atau industri dan perusahaan diwajibkan untuk memenuhi ketentuan di peraturan tersebut, misalkan Undangundang Ketenagakerjaan, Undang-undang jaminan sosial dan lainnya.

3. Imbalan yang tidak diatur secara formal di perusahaan, tetapi bersifat konstruktif (atau bersifat menjadi kebiasaan dan keharusan). Misalkan bonus apabila perusahaan laba. 
Jika dilihat dari jenis imbalan kerja yang termasuk ke dalam definisi imbalan kerja di PSAK 24 adalah:

1. Imbalan Kerja Jangka Pendek, Imbalan Kerja yang jatuh tempo kurang dari 12 bulan. Misalkan Gaji, iurang jaminan sosial, cuti tahunan, cuti sakit, bagi laba dan bonus, dan imbalan yang tidak berbentuk uang.

2. Imbalan Pasca Kerja, imbalan kerja yang diterima pekerja setelah pekerja sudah tidak aktif lagi bekerja. Misalkan Imbalan Pensiun, Imbalan asuransi jiwa pasca kerja, imbalan kesehatan pasca kerja.

3. Imbalan Kerja Jangka Panjang, Imbalan Kerja yang jatuh tempo kurang dari 12 bulan. Misalkan Cuti besar/cuti panjang, penghargaan masa kerja (jubilee) berupa sejumlah uang atau berupa pin/cincin terbuat dari emas dan lain-lain.

4. Imbalan Pemutusan Kontrak Kerja (PKK), imbalan kerja yang diberika karena perusahaan berkomitmen untuk:

a. Memberhentikan seorang atau lebih pekerja sebelum mencapai usia pensiun normal, atau

b. Menawarkan pesangon PHK untuk pekerja yang menerima penawaran pengunduran diri secara sukarela (golden shake hand).

Terdapat faktor ketidakpastian (uncertainty factor) dalam perhitungan PSAK 24 yang disebabkan oleh:

1. Apakah semua karyawan di satu perusahaan akan tetap bekerja sampai dengan usia pensiun?

2. Dalam rentang usia seorang pekerja, pasti ada kemungkinan-kemungkinan meninggal dunia, sakit berkepanjangan atau cacat. Berapakah besarnya peluang dari kemungkinan-kemungkinan tersebut?

3. Dalam dunia kerja sudah menjadi hal yang lumrah pekerja mengundurkan diri, untuk menghitung kemungkinan beban imbalan pasca kerja dari mengundurkan diri . Berapa besar kemungkinan pekerja mengundurkan diri?

4. Berapakah gaji seorang pekerja ketika memasuki usia pensiun?

5. Dan faktor-faktor lainnya yang tidak pasti. PSAK24telahmengaturtatacaraperhitungan beban imbalan kerja yang terdapat unsur ketidakpastian tersebut dengan menggunakan ilmu Aktuaria. Aktuaria adalah suatu ilmu pengetahuan yang merupakan kombinasi dari ilmu statistik, matematika dan ekonomi yang digunakan untuk memperkirakan suatu nilai dengan data dan asumsi yang telah ditentukan. Meskipun dalam PSAK 24 tidak disebutkan keharusan menggunakan jasa konsultan aktuaria untuk menentukan beban imbalan kerja, alasan professionalisme, independensi dan efisiensi menjadi dasar perusahaan menggunakan jasa aktuaris. Dalam penyusunan laporan keuangan audited perusahaan, auditor melakukan cek validasi laporan aktuaris atas perhitungan PSAK 24, apakah sesuai dengan PSAK 24 yang dikeluarkan oleh DSAK-IAI atau belum.

Perubahan aktuarial dalam imbalan kerja manfaat pasti (PSAK 24) selama tahun pengamatan nampak peningkatan pada tahun 2014 dan tahun 2015. OCI yang berasal dari imbalan kerja disebabkan karena adanya keuntungan dan kerugian aktuarial. Keuntungan dan kerugian aktuarial disebabkan oleh 2 hal yaitu:

1. Penyesuaian pengalaman (merupakan perubahan atas nilai kini dari kewajiban imbalan pasti sebagai akibat dari perbedaan antara asumsi aktuarial awal dengan aktualnya),

2. Pengaruh perubahan asumsi aktuarial.

\section{Pendapatan Komprehensif Lain : Sekuritas Tersedia untuk Dijual}

Perkembangan yang terjadi pada PSAK 55 terkait dengan sekuritas tersedia untuk dijual terhadap perusahaan dalam sektor aneka industri yang tercatat di Bursa Efek Indonesia dalam kurun waktu tahun 2012 sampai dengan tahun 
2015 tidak lebih dari 17\%. Dimana tercatat yang menyajikan terhadap PSAK 55 hanya 3 perusahaan yang tergabung dalam subsektor otomotif dan komponen, 1 perusahaan untuk subsektor tekstil dan garment, 2 perusahaan untuk subsektor kabel, dan sedangkan untuk subsektor elektronika dan alas kaki tidak menyajikan dalam kurun waktu tahun 2012 sampai dengan tahun 2015. Pada tahun 2012 dan tahun 2013 tercatat yang menyajikan PSAK 55 terkait dengan sekuritas tersedia untuk dijual ini adalah sebesar $14,3 \%$. Sedangkan pada tahun 2014 dan tahun 2015 mengalami kenaikan yang tidak terlalu banyak, yaitu dengan nominal keseluruhan sebesar 16,7\%.

Aset keuangan tersedia untuk dijual adalah aset keuangan nonderivatif yang ditetapkan sebagai tersedia untuk dijual atau yang tidak diklasifikasikan sebagai (a) pinjaman yang diberikan dan piutang, (b) investasi yang diklasivikasikan dalam kelompok dimiliki hingga jatuh tempo, atau (c) aset keuangan yang diukur pada nilai wajar melalui laba rugi. Kontrak jaminan keuangan adalah kontrak yang mensyaratkan penerbit untuk melakukan pembayaran tertentu untuk mengganti pemegang atas timbulnya kerugian karena debitur tertentu gagal melakukan pembayaran pada saat jatuh tempo sesuai dengan persyaratan awal atau persyaratan yang telah dimodifikasi dari suatu instrument utang. Biaya perolehan diamortisasi dari aset keuangan atau liabilitas keuangan adalah jumlah aset keuangan atau liabilitas keuangan yang diukur pada pengakuan awal dikurangi pembayaran pokok, ditambah atau dikurangi dengan amortisasi kumulatif menggunakan metode suku bunga efektif yang dihitung dari selisih antara nilai awal dan nilai jatuh temponya, dan dikurangi penurunan untuk penurunan nilai atau nilai yang tidak dapat ditagih

\section{Pendapatan Komprehensif Lain : Lindung Nilai}

Perkembangan yang terjadi pada PSAK 55 terkait dengan lindung nilai terhadap perusahaan dalam sektor aneka industri yang tercatat di Bursa Efek Indonesia dalam kurun waktu tahun 2102 sampai dengan tahun 2015 tidak lebih dari $8 \%$. Berdasarkan data yang diperoleh pada penelitian ini bahwa emiten yang melakukan penyajian PSAK 55 terkait dengan lindung nilai ini adalah yang tergolong pada subsektor otomotif dan komponen saja. Pada tahun 2012 tercatat bahwa yang menyajikan PSAK 55 terkait dengan lindung ini sebesar 7,1\%. Kemudian terjadi penurunan pada tahun 2013 yaitu menjadi 2,4\%. Pada tahun berikutnya di 2014 terjadi peningkatan yang tidak banyak dan sama jumlahnya dengan tahun 2015 yaitu sebesar 4,8\%.

Suatu entitas yang memiliki atau menerbitkan instrument derivatif (atau nonderivatif yang ditujukan untuk dan memenuhi syarat sebagai instrumen lindung nilai harus mengungkapkan tujuan pemilikan atau penerbitan instrumen tersebut, latar belakang yang diperlukan untuk memahami tujuan tersebut, dan strategi untuk mencapai tujuan tersebut. Penjelasan yang dibuat harus dapat membedakan antara instrumen derivatif (dan instrumen nonderivatif) yang ditujukan sebagai instrumen lindung nilai wajar, instrument derivatif yang ditujukan sebagai instrumen lindung nilai arus kas, instrumen derivatif (dan instrumen non-derivatif) yang ditujukan sebagai instrumen lindung nilai atas risiko valuta asing dari investasi bersih pada kegiatan usaha di luar negeri, dan derivatif yang lain.

Penjelasan tersebut juga harus mengindikasikan kebijakan manajemen risiko entitas yang bersangkutan untuk setiap jenis lindung nilai, termasuk penjelasan mengenai aktiva/ kewajiban dan jenis transaksi yang dilindungi. Untuk instrumen derivatif yang tidak ditujukan sebagai instrumen lindung nilai, penjelasan yang dibuat harus menyatakan tujuan dari aktivitas derivatif yang dilakukan. Pengungkapan 
kualitatif mengenai tujuan dan strategi entitas tersebut untuk penggunaan instrumen derivatif akan lebih bermanfaat jika tujuan dan strategi dijelaskan sehubungan dengan profil manajemen risiko keseluruhan dari entitas yang bersangkutan. Jika memung-kinkan, suatu entitas disarankan, tetapi tidak diharuskan untuk memberikan pengungkapan kualitatif tambahan seperti yang dijelaskan di atas.

\section{Pendapatan Komprehensif Lain : Revaluasi}

\section{Aset}

Perkembangan yang terjadi pada PSAK 16/19 terhadap perusahaan dalam sektor aneka industri yang tercatat di Bursa Efek Indonesia dalam kurun waktu tahun 2102 sampai dengan tahun 2015 tidak lebih dari 12\%. Pada tahun 2012 penyajian PSAK 16/19 pada perusahaan sektor aneka industri ini tercatat hanya 9,5\% yang menyajikan, pada tahun 2013 terjadi penurunan menjadi sebesar $4,8 \%$. Pada tahun 2014 terjadi penngkatan yang cukup tajam dalam penyajian PSAK 16/19 ini yaitu dengan total peningkatan sebesar $11,9 \%$. Pada tahun 2015 terjadi penurunan kembali menjadi 7,1\%.

Revaluasi aset tetap sesuai dengan PSAK 16 (Aset Tetap) atau revaluasi aset tak berwujud (PSAK 19) akan berdampak pada OCI jika metode yang digunakan adalah metode revaluasi. Nilai $O C I$ bertambah jika terdapat selisih lebih antara nilai pasar dibandingkan nilai buku. Rugi atas revaluasi tidak masuk dalam $O C I$ namun diakui sebagai komponen laba rugi jika sebelumnya telah dilakukan revaluasi maka nilai OCI menjadi saling hapus. Temuan penelitian menunjukkan bahwa proporsi perusahaan yang melakukan revaluasi menurun, namun cenderung stabil. Hal ini diduga disebabkan karena adanya peraturan bahwa keuantungan revaluasi berdampak terhadap pembayaran pajak secara final 10\% kecuali untuk akhir tahun 2015 terdapat keringanan pajak menjadi bertarif $3 \%$.

\section{Pendapatan Komprehensif Lain : Entitas} Asosiasi

Perkembangan yang terjadi pada PSAK 15 terkait dengan entitas asosiasi terhadap perusahaan dalam sektor aneka industri yang tercatat di Bursa Efek Indonesia dalam kurun waktu tahun 2012 sampai dengan tahun 2015 terjadi merata, yaitu sebesar $7,10 \%$. Adapun emiten yang melakukan penyajian dalam PSAK 15 terkait dengan entitas asosiasi ini adalah emiten yang tergabung dalam subsektor otomotif dan komponen sebanyak 3 emiten, yaitu PT Astra International Tbk, kemudian PT Astra Otoparts Tbk, dan PT Gajah Tunggal Tbk.

Entitas asosiasi adalah suatu entitas dimana Grup mempunyai pengaruh yang signifikan dan bukan merupakan entitas anak ataupun bagian partisipasi dalam ventura bersama. Pengaruh signifikan adalah kekuasaan untuk berpartipasi dalam keputusan kebijakan keuangan dan operasional investee tetapi tidak mengendalikan atau mengendalikan bersama atas kebijakan tersebut. Suatu entitas dikatakan berelasi jika satu entitas adalah entitas asosiasi atau ventura bersama dari entitas lain (atau entitas asosiasi atau ventura bersama yang merupakan anggota suatu kelompok usaha, yang mana entitas lain tersebut adalah anggotanya). PSAK 15 mengatur perlakuan akuntansi terkait asosiasi dan ventura bersama. Pada sampel yang diteliti penyajian nilai yang diakibatkan penilaian kembali atas nilai wajar yang diakibatkan kegiatan asosiasi relatif rendah. Berikut penjelasan penting dalam pengumgkapan laporan keuangan terkait asosiasi dan ventura.

Selisih antara jumlah tercatat sebelumnya atas entitas asosiasi diatribusikan ke sisa kepemilikan dan nilai wajar termasuk dalam penentuan keuntungan atau kerugian atas pelepasan entitas asosiasi. Selanjutnya, Grup memperhitungkan seluruh jumlah yang sebelumnya diakui dalam pendapatan komprehensif lain yang terkait dengan entitas asosiasi tersebut dengan menggunakan dasar yang sama dengan yang diperlukan jika entitas 
asosiasi telah melepaskan secara langsung aset dan liabilitas yang terkait. Oleh karena itu, jika keuntungan atau kerugian yang sebelumnya telah diakui dalam pendapatan komprehensif lain oleh entitas asosiasi akan direklasifikasi ke laba rugi atas pelepasan aset atau liabilitas yang terkait, maka Grup mereklasifikasi keuntungan atau kerugian dari ekuitas ke laba rugi (sebagai penyesuaian).

\section{Pendapatan Komprehensif Lain : Ventura Bersama}

Perkembangan yang terjadi pada PSAK 15 terkait dengan ventura terhadap perusahaan dalam sektor aneka industri yang tercatat di Bursa Efek Indonesia dalam kurun waktu tahun 2012 dan tahun 2013 adalah sama, yaitu yaitu sebanyak 2 perusahaan atau setara dengan 4,8\%. Pada tahun $20140 \%$, tidak ada perusahaan dalam sektor industri ini yang menyajikan. Pada tahun 2015 ada yang menyajikan kembali sebanyak 1 perusahaan atau setara dengan 2,4\%.

Dalam melakukan suatu kegiatan investasi tidak semua investasi dapat dilakukan dengan mudah, karena hampir semua investasi mengandung suatu risiko keru-gian. Bagi investasi yang mempunyai risiko rendah, hampir semua investor ingin melakukannya. Akan tetapi, jika investasi tersebut memiliki risiko tinggi, maka tidak mudah untuk mencari investor yang mau melakukannya. Yang berani melakukan investasi dimana investasi tersebut mengandung suatu risiko tinggi adalah perusahaan modal ventura.

Hal-hal yang mencakup tentang Ventura adalah sebagai berikut:

1. Pembiayaan modal ventura terutama diberikan kepada perusahaaan yang baru mulai tumbuh dan biasanya belum mendapat kepercayaan oleh lembaga perbankan untuk memperoleh kredit bank.

2. Pembiayaan modal ventura merupakan pembiayaan yang berisiko tinggi, tetapi juga merupakan pembiayaan yang memiliki potensi keuntungan yang tinggi pula yang biasanya didapatkan melalui keuntungan yang didapat dari hasil penjualan dan penanaman modal yang bersifat jangka menengah atau jangka panjang.

3. Pembiayaan modal ventura merupakan investasi atau penanaman dana jangka panjang.

4. Pembiayaan modal ventura biasanya dilakukan dalam bentuk penyertaan modal dan atau pinjaman yang bias dialihkan menjadi saham kepada perusahaan-perusahaan yang berpotensi untuk berkembang.

5. Pembiayaan modal ventura biasanya dilakukan dalam bentuk paket pembiayaan, yaitu suntikan dana atau modal yang disertai dengan penempatan atau pembinaan manajemen pada perusahaan pasangan usaha.

6. Pembiayaan modal ventura juga un-tuk mendukung bakat-bakat wirausaha dengan kemampuan finansial untuk memanfaatkan pasar dengan jalan alih manfaat yang diberikan dalam dam-pingan manajemen oleh perusahaan pemodal ventura.

Modal ventura merupakan investasi aktif, yang memasukkan modal ke dalam suatu perusahaan yang biasanya disertai dengan keterlibatan seperti manajemen keuangan, pemasaran dan pengawasan operasional. Modal ventura dapat juga dimasukkan ke dalam suatu usaha untuk waktu sementara yang bertujuan untuk menarik kembali modal yang ditanam setelah usaha berjalan lancer dan nilai perusahaan meningkat. Keuntungan modal ventura diharapkan datang dari apresiasi nilai saham atau capital gain.

Pendirian perusahaan modal ventura bukanlah tanpa ada tujuan dan manfaat. Sebagai lembaga bisnis, usaha modal ventura sudah tentu berorientasi untuk memperoleh keuntungan yang besar mengingat usaha ini mempunyai tingkat resiko yang tinggi (high risk). Meskipun demikian, bukan berarti usaha modal ventura ini tidak mempunyai misi humanistik (humanistic institution), yaitu lembaga penolong bagi usaha yang masih lemah. 
Secara umum perkembangan penyajian komponen $O C I$ mengalami peningkatan pada penjabaran mata uang asing untuk kepentingan pelaporan keuangan, imbalan kerja, revaluasi aset dan instrument keuangan baik sekuritas yang tersedia untuk dijual maupun lindung nilai. Adapun komponen $O C I$ yang lainnya, relative tidak banyak disajikan, yaitu selisih nilai wajar yang diakibatkan oleh asosiasi dan ventura bersama.

\section{Perbedaan Penyajian Komponen Other Comprehensive Income}

Transaksi Other Comprehensive Income (OCI) dalam International Financial Report Standard (IFRS) lebih banyak terjadi disebabkan karena penilaian terhadap nilai wajar yang menyakut penjabaran mata uang asing, revaluasi aset, perubahan aktuarial dalam imbalan kerja manfaat pasti, perubahan nilai wajar investasi yang tersedia dijual, perubahan nilai wajar lindung nilai dan perubahan nilai atas asosiasi dan ventura bersama. Hasil pengamatan dan investigasi selama 4 tahun sejak diterapkan IFRS secara mandatory pada sektor aneka industri.

Tabel.2.

Rangkuman Hasil Pengujian Hipotesis 1 s/d 7 Sektor Aneka Industri tahun 2012-2015

\begin{tabular}{lcll}
\hline \multicolumn{1}{c}{ Komponen $\boldsymbol{O C I}$} & Prob. Sig & \multicolumn{1}{c}{ Keterangan } & Simpulan \\
\hline PSAK 10 - Selisih Kurs & 0.000 & Siginifikan & Beda \\
PSAK 24 - Imbalan Kerja & 0.479 & Tidak Signifikan & Tidak Beda \\
PSAK 55 - AFS & 0.001 & Siginifikan & Beda \\
PSAK 55 - Heding & 0.002 & Siginifikan & Beda \\
PSAK 16/19 - Rev. Aset & 0.001 & Siginifikan & Beda \\
PSAK 15 - Asosiasi & 0.000 & Siginifikan & Beda \\
PSAK 15 - Ventura & 0.736 & Tidak Signifikan & Tidak Beda \\
\hline
\end{tabular}

\section{Simpulan, Keterbatasan, dan Impilkasi Hasil Peneltian}

Penelitian ini bertujuan untuk menginvestigasi penyajian laporan laba rugi dan penghasilan komprehensif lain pada sektor aneka industri yang difokuskan pada penyajian komponen-komponen Other Comprehensive Income. Penyajian OCI merupakan penyajian yang berasal dari selisih lebih dan atau selisih kurang terkait nilai selisih kurs, imbalan kerja, sekuritas yang tersedia untuk dijual, lindung nilai, penilaian asosiasi, dan ventura bersama. Riset ini dimotivasi oleh pemberlakukan secara wajib Pernyataan Standar Akuntansi Keuangan (PSAK) berbasis International Financial Reporting Standards (IFRS). Penelitian ini penting utk dilakukan karena komponen OCI pada beberapa penelitian sebelumnya terbukti memiliki relevansi nilai. Informasi OCI merupakan informasi yang dibutuhkan oleh pemerintah terkait pengenaan pajak atas penyajian. Penelitian ini mengobservasi sejumlah 168 sampel yang terdiri dari Subsektor Mesin dan Alat Berat, Subsektor Otomotif dan Komponen, Subsektor Tekstil dan Garment, Subsektor Alas Kaki (Footwear), Subsektor Kabel dan Subsektor Elektronika.

Investigasi dilakukan dengan melakukan pengamatan perkembangan penyajian other comprehensive income (OCI) dan komponennya mulai tahun 2012 sampai dengan 2015 secara keseluruhan maupun berdasarkan subsektor aneka industri. Uji beda penyajian dilakukan dengan Uji Cramer V karena data berskala nominal. Pengujian tidak memerlukan asumsi normalitas karena termasuk kelompok statistik nonparametrik. 
Berdasarkan hasil investigasi dan pengujian hipotesis pada sektor aneka industri ini dapat disimpulkan beberapa hal sebagai berikut:

1. Penyajian $O C I$ terkait selisih kurs pada laporan laba rugi dan penghasilan komprehensif lain mengalami peningkatan/ penurunan selama periode waktu observasi. Selama 4 tahun pengamatan $25,6 \%$ perusahaan melakukan penyajian selisih kurs. Berdasarkan penyajiannya subsektor industri otomotif dan komponen paling banyak menyajikan akun tersebut.

2. Penyajian $O C I$ terkait selisih imbalan kerja pada laporan laba rugi dan penghasilan komprehensif lain mengalami peningkatan/ penurunan selama periode waktu observasi. Selama 4 tahun pengamatan terdapat $41,1 \%$ perusahaan yang melakukan penyajian selisih imbalan kerja. Berdasarkan penyajiannya subsektor industri otomotif dan komponen serta tekstil dan garment paling banyak menyajikan akun tersebut.

3. Penyajian $O C I$ terkait selisih nilai sekuritas yang tersedia untuk dijual pada laporan laba rugi dan penghasilan komprehensif lain mengalami peningkatan/penurunan selama periode waktu observasi. Selama 4 tahun pengamatan $15,5 \%$ perusahaan yang melakukan penyajian selisih nilai sekuritas tersedia untuk dijual. Berdasarkan penyajiannya subsektor industri otomotif dan komponen paling banyak menyajikan akun tersebut.

4. Penyajian $O C I$ terkait selisih nilai lindung nilai/hedging yang tersedia untuk dijual pada laporan laba rugi dan penghasilan komprehensif lain mengalami peningkatan/ penurunan selama periode waktu observasi. Selama 4 tahun pengamatan $4,8 \%$ perusahaan yang melakukan penyajian selisih nilai indung nilai/hedging. Berdasarkan penyajiannya subsektor industri otomotif dan komponen paling banyak menyajikan akun tersebut.

5. Penyajian $O C I$ terkait revaluasi aset tetap berwujud dan tidak berwujud pada laporan laba rugi dan penghasilan komprehensif lain mengalami peningkatan/penurunan selama periode waktu observasi. Selama 4 tahun pengamatan $8,3 \%$ perusahaan melakukan penyajian revaluasi aset tetap berwujud dan tidak berwujud. Berdasarkan penyajiannya subsektor industri otomotif dan komponen paling banyak menyajikan akun tersebut.

6. Penyajian $O C I$ terkait selisih nilai asosiasi pada laporan laba rugi dan penghasilan komprehensif lain mengalami peningkatan/ penurunan selama periode waktu observasi. Selama 4 tahun pengamatan 7,1\% perusahaan melakukan penyajian selisih nilai asosiasi. Berdasarkan penyajiannya. subsektor industri otomotif dan komponen paling banyak menyajikan akun tersebut.

7. Penyajian $O C I$ terkait selisih nilai ventura yang tersedia untuk dijual pada laporan laba rugi dan penghasilan komprehensif lain mengalami peningkatan/penurunan selama periode waktu observasi. Selama 4 tahun pengamatan $3 \%$ perusahaan melakukan penyajian selisih nilai ventura. Berdasarkan penyajiannya subsektor industri otomotif dan komponen paling banyak menyajikan akun tersebut.

8. Pengujian hipotesis untuk menguji perbedaan penyajian 7 komponen $O C I$ memberikan bukti bahwa 5 hipotesis terbukti dan 2 tidak berhasil dibuktikan. Adapun rincian terkait dengan hasil pengujian tersebut adalah sebagai berikut:

a. Hipotesis terkait selisih kurs $\left(\mathrm{H}_{1}\right)$ sekuritas tersedia untuk dijual $\left(\mathrm{H}_{3}\right)$, selisih lindung nilai/heding $\left(\mathrm{H}_{4}\right)$, revaluasi aset tetap berwujud dan tidak berwujud $\left(\mathrm{H}_{5}\right)$, selisih nilai asosiasi $\left(\mathrm{H}_{6}\right)$ ditemukan adanya perbedaan penyajian pada laporan laba rugi dan penghasilan komprehensif lain.

b. Hipotesis terkait selisih imbalan kerja $\left(\mathrm{H}_{2}\right)$ dan selisih nilai ventura $\left(\mathrm{H}_{7}\right)$ tidak ditemukan adanya perbedaan penyajian pada laporan laba rugi dan penghasilan komprehensif lain. 
Penelitian ini mengambil satu kelompok sampel sektor aneka industri beserta dengan subsektor-subsektor didalamnya. Hasil observasi hanya berlaku untuk sektor industri tersebut dan tidak berlaku untuk sektor industri lain yang terdaftar di Bursa Efek Indonesia. Demikian juga dengan hasil uji beda. Temuan perbedaan tidak dapat digeneralisasi untuk keseluruhan sektor industri. Namun secara khusus pembuktian hipotesis berlaku untuk sektor industri yang diobservasi.

Berdasarkan hasil, keterbatasan dan kendala yang ditemukan dalam penelitian ini disaranakan beberapa hal sebagai beriikut. Peneliti menggunakan rentan waktu dari data panel selama 4 (empat) tahun yang telah terdaftar dalam BEI, akan lebih baik jika data yang digunakan adalah data komperatif yang mempunyai ruang lebih luas.Bagi peneliti berikutnya, hasil penelitian ini merupakan dasar dilakukannya riset-riset lanjutan terkait pendapatan komprehensif lain $(O C I)$ seperti faktor apa yang mempengaruhi $O C I$ dan konsekuensi yang diakibatkan oleh informasi OCI. Bagi pemerintah, hasil penelitian ini merupakan informasi penting yang dapat digunakan sebagai salah satu informasi pendapatan pajak karena selisih nilai komponen $O C I$ merupakan dikenai pajak. Hasil penelitian ini memberikan informasi tentang besarnya nilai $O C I$ dimana nilai $O C I$ meskipun secara riil bukan berupa kas namun nilai tersebut dapat merupakan informasi yang mampu menambah nilai perusahaan, misalnya terkait dengan peningkatan nilai asset tetap yang tercermin pada revaluasi asset.

\section{Daftar Referensi}

Brigham, Eugene F., Joel F. Houston, (2001). Dasar-Dasar Manajemen Keuangan. Edisi ke 8, Salemba Empat, Jakarta.

Cahyati,A.D. (2011). "Peluang Manajemen Laba Pasca Konvergensi IFRS: Sebuah Tinjauan Teoritis dan Empiris". JRAK Vol.2 No.1. Hal 1-7
Gamayuni, Rindu Rika. (2009). Perkembangan Standar Akuntansi Keuangan Indonesia Menuju International Financial Standards. Jurnal Akuntansi dan Keuangan Vol 14 No 2, Juli 2009.

Hasnawati, Sri. Implikasi Keputusan Investasi, Pendanaan, dan Dividen Terhadap Nilai Perusahaan Publik di Bursa Efek Jakarta. Usahawan Indonesia34.9 (2005): 33-41.

Humayun Kabir, M., and Fawzi Laswad. Properties Of Net Income and Total Comprehensif Income; New Zealand evidence. Accounting Research Journal 24.3 (2011): 268289.

Lestari, Y. O. (2011). "Konvergensi International Financial Reporting Standards (IFRS) dan Manajemen Laba di Indonesia”. El Muhasaba ISSN 2086-1249 Vol 2 NO 2. Hal 1-22.

Indonesian Stock Exchange, website: http:// www.idx.co.id . Annual Report - Financial Statement, periode 2012-2015.

Kieso, Donald E, Weygandt, Jerry J., Warfield, Terry D, (2007). Intermediate Accounting, Edisi dua belas. Jilid satu. Jakarta. Erlangga.

Sakirman, (2016). Pengaruh Net Income, Daya Informasi, Pendapatan Komprehensif Lain Terhadap Return Saham Dengan Kualitas Audit Sebagai Variabel Pemoderasi, Tesis, Universitas Pancasila, Jakarta.

Sugiyono, (2002). Metode Penelitian Bisnis. Cetakan ke 9. Bandung: Alfabeta.

Majalah Kontan Online, website: http:// www.kontan.co.id. (2016).

Werner, Edward M. The Value Relevance of Pension Accounting Information: evidence from Fortune 200 firms. Review of Accounting and Finance 10.4 (2011): 427-458.

Velashani,Ali Saeedi, (1999). Examining the Superiority of Comprehensive Income to Net Income as a Measure of Firm Performance. Europan Journal of Economic. Financial and Administrative Sciences. 